\title{
Role of general practitioner in the management of acute myocardial infarction
}

\author{
Beeleonie, Dede Kusmana
}

\begin{abstract}
Abstrak
Infark miokard akut (IMA) telah menjadi sebab utama kematian di negara Barat maupun di Indonesia. Keterlambatan diagonis dan tatalaksana dini yang salah seringkali mengakibatkan kegagalan reperfusi dengan trombolitik. Dokter umum sebagai lini kesehatan pertama harus dibekali dengan ketrampilan mendiagnosis dan juga menangani IMA. Dalam tulisan ini dilaporkan kasus gagal terapi trombolitik pada pria usia 47 tahun setelah tujuh jam mengalami nyeri dada angina, yang telah sebelumnya ditangani oleh dokter umum. (Med J Indones 2005; 14:249-52)
\end{abstract}

\begin{abstract}
Acute myocardial infarction (AMI) has been the leading cause of death in Western countries, as well as in Indonesia. Delay in diagnosis and incorrect early management often result in failure of thrombolytic reperfusion. General practitioner (GP) as the primary care, needs to be equipped with the ability to diagnose and moreover to manage AMI. A case of fail thrombolytic management in a 47 years old man after seven hours of angina typical chest pain, after previously managed by GP, is being reported. (Med J Indones 2005; 14:249-52)
\end{abstract}

Keywords: acute myocardial infarction, reperfusion, general practitioner

Acute myocardial infarction (AMI) is sudden occlusion of a coronary artery leading to imbalance of oxygen supply and demand of the myocardium, resulting in myocardial cell death. ${ }^{1}$ Thrombolytics have been the standard of care for AMI management. ${ }^{2}$ Thrombolytic is best given within six hours after the onset of chest pain to salvage the myocardial muscle through early reperfusion. $^{3}$ Little myocardial salvage is expected beyond 6 hours, especially if the chest pain and ST segment elevation has settled. ${ }^{3}$

Hence, a correct diagnosis of AMI as early as possible is needed for a successful reperfusion. The delay in diagnosis and management of AMI patient often caused by the delay to call for help, ambulance response time, transportation to hospital, as well as the incompetence of the primary care giver, where the patient seek first for help.

Department of Cardiology, Faculty of Medicine, University of Indonesia/National Cardiac Center Harapan Kita, Jakarta, Indonesia

\section{CASE REPORT}

A patient was presented to emergency department with severe pain on the left chest 7 hours before admission. The pain radiates to the left arm, neck and back, accompanied by sweating. This was the first onset of pain and it persisted for 20 minutes. The pain started at rest and was reduced with sublingual ISDN (Isosorbite Dinitrate) and $8 \mathrm{mg}$ of Aspilet given by a GP few hours after the onset of chest pain. He had been smoking three packages cigarettes per day for 20 years. He did not have any other risk factor for CAD. On physical examination, blood pressure was 120/65 $\mathrm{mmHg}$ and heart rate was $72 \mathrm{x} / \mathrm{min}$, regular. The ECG showed ST segment elevation in V1-V3, T wave inverted in aVL, V1-V4, QS wave in V1-V3. There was no abnormal finding on systemic examinations. The biochemical and hematological tests were normal, including total cholesterol, LDL, HDL, and triglycerides level.

Based on the typical chest pain and ECG finding, the patient was diagnosed with acute anterior myocardial infarction onset 7 hours killip I. The patient was managed with streptokinase 1.5 million IU, Aspirin 
160 mg, Laxadin 1x CI, Diazepam 1x 5mg, Cedocard 5L $5 \mathrm{~g}$, Ascardia 1x80 mg, ISDN 3x5 mg, Metoprolol 2x $12.5 \mathrm{mg}$, and Captopril 3x $6.25 \mathrm{mg}$ (titrate). In the first 24 hours follow-up result, both cardiac enzyme CKMB and troponin T were increased to $137 \mathrm{U} / \mathrm{L}$ and $0.523 \mathrm{~g} / \mathrm{ml}$, respectively. Echocardiography showed left ventricle hypertrophy ( $\mathrm{LVH})$ concentric, hypokinetic anterior wall, with ejection fraction $48 \%$.
Post-thrombolytic, patient still complain of chest pain and the ECG showed no resolution of ST-segment elevation and no reperfusion arrhythmia. The patient was treated conservatively and the pain was disappeared and afterward discharges from the hospital with myocardial sequel.
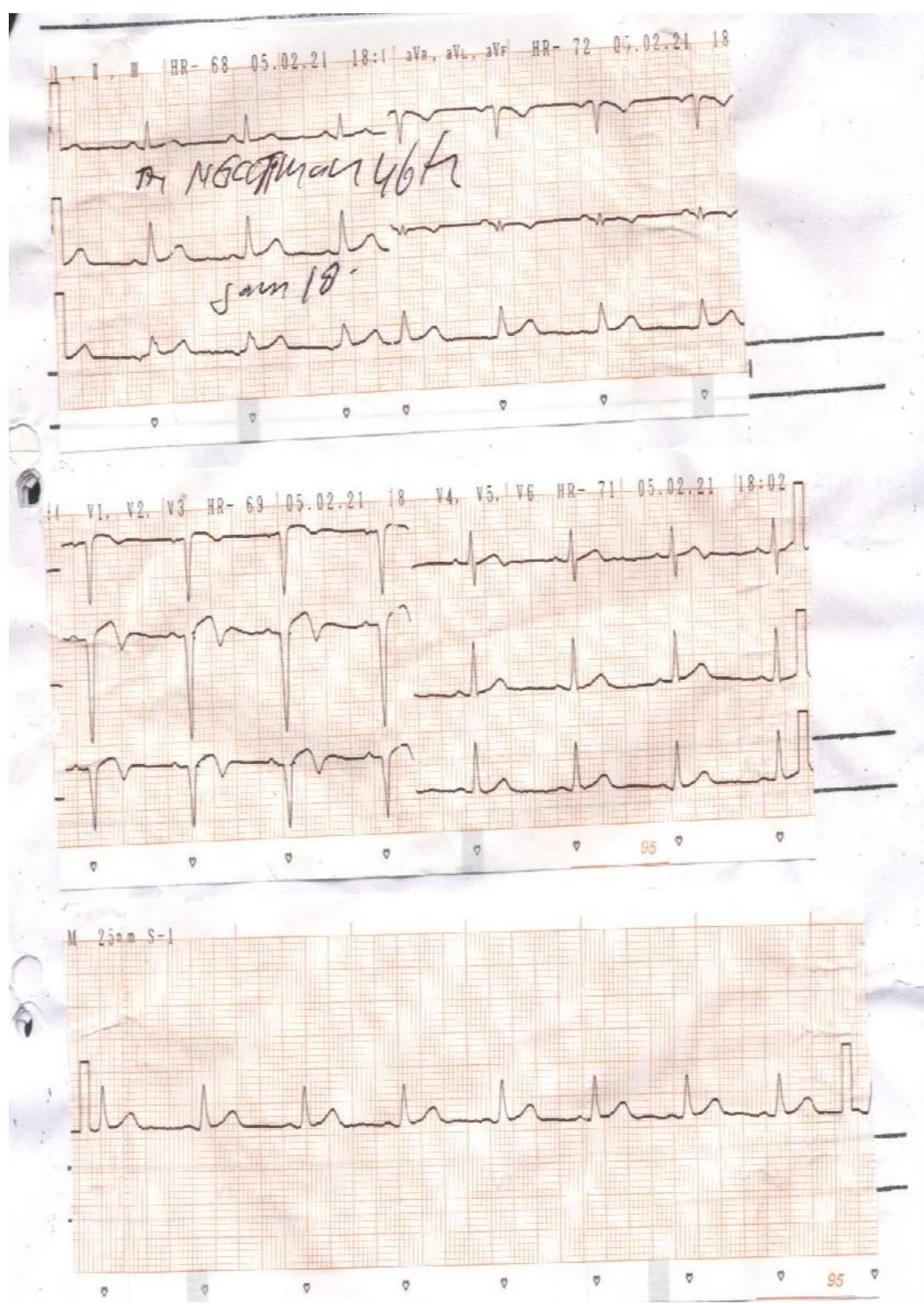

Figure 1. ECG showing ST segment elevation in V1-V3, T wave inverted in aVL, V1-V4, QS wave in V1-V3 


\section{DISCUSSION}

The diagnosis criteria of AMI (The American Heart Association and American College of Cardiology 1996) consists of typical chest pain, ECG with characteristic changes suggesting myocardial infarction, and cardiac-specific biochemical markers exceeding the standard reference range in a pattern consistent with AMI. ${ }^{4}$ Two of the three findings are necessary to diagnose $\mathrm{AMI}^{4}$

The recognition of typical chest pain of angina, along with high risk age and sex group was shown to be $92 \%$ accurate in prediction of AMI. $^{5}$ Hence, GP should be able to differentiate angina to non-angina chest pain in pre-hospital setting.

However, another study argued that diagnosis made based on typical chest pain alone often lead to false diagnosis, where not all AMI patient present with typical angina chest pain. ${ }^{6}$ Thus, 12-lead electrocardiography (ECG) is needed for diagnosis. An ECG showing ST-segment elevation $(\geq 0.1 \mathrm{mV})$ in contiguous leads provides strong evidence of thrombotic coronary artery occlusion. ${ }^{4}$ Unfortunately, most GP in Indonesia are not equipped with the ability of ECG monitoring and interpretation. Moreover, ECG is not always available in GP daily practice or health clinics (Puskesmas). In such case, GP will have to refer the patient to cardiologist or center with ECG facility.

In this presented case, the initial management by the GP was based on the recognition of angina typical chest pain only. Patient was then referred to cardiovascular hospital for ECG monitoring and further management. Although, the initiative for referral by the GP is acceptable, patient arrived too late. This practical reality urges us, the physicians that it is now the time to make changes in managing AMI.

First, GP as the first line physician need to know when a patient present with chest pain require referral. Second, GP should also be equipped with ECG monitoring and interpretation skill. It is then; best to start include ECG skill in the undergraduate study program. A study conducted in Merseyside area, England showed that from $150 \mathrm{GP}$, only $82 \%$ could correctly diagnose AMI based on ECG interpretation, suggesting that training for GP is also needed in a regular basis. ${ }^{7}$ Third, ECG facility should be available in all primary care centers, including those in remote areas.
Finally, the ideal way to shorten time to thrombolytic treatment is pre-hospital thrombolysis. The European Task Force Report recommends that thrombolytic treatment should be administered by the first qualified person evaluating the patient. ${ }^{8}$ A system of prehospital thrombolysis delivered by paramedics with hospitalbased decision under strict protocol has been found to be effective. ${ }^{9,10}$ In Sweden, for example, two thirds of hospital have got a pre-hospital thrombolysis treatment by well trained paramedics or nurses in ambulance. ${ }^{11}$ Nurses in England has also shown to be capable of administering thrombolytic in coronary care setting. ${ }^{12}$

In Indonesia medical setting, GP will be the ideal medical professional eligible for pre-hospital thrombolysis. This concept may be suitable for Indonesia, where majority of the population are in rural area. Hence, GP should be well trained on how to perform thrombolysis, the indication and contraindication, as well as the best choice of thrombolytic agent.

In summary, it is practically impossible for cardiologist to attend all primary care centers. Therefore, management of AMI should involve general practitioner. This includes recognition of the characteristic chest pain, the typical ECG changes, and administration of thrombolytic therapy.

\section{REFERENCES}

1. Danchin N, Urban P, De Benedetti E. Acute myocardial infarction. Clin Evid. 2002(7):11-35.

2. Ryan TJ. Management of acute myocardial infarction. Synopsis of ACC and AHA practice guidelines. American College of Cardiology and American Heart Association. Postgrad Med 1997;102(5):84-8, 91-83, 96.

3. Indications for fibrinolytic therapy in suspected acute myocardial infarction: collaborative overview of early mortality and major morbidity results from all randomised trials of more than 1000 patients. Fibrinolytic Therapy Trialists' (FTT) Collaborative Group. Lancet 1994; 343(8893):311-22.

4. Ryan TJ, Melduni RM. Highlights of latest American College of Cardiology and American Heart Association Guidelines for Management of Patients with Acute Myocardial Infarction. Cardiol Rev 2002;10(1):35-43.

5. Anderson HV, King SB, 3rd. Modern approaches to the diagnosis of coronary artery disease. Am Heart $\mathbf{J}$ 1992;123(5):1312-23.

6. Canto JG, Shlipak MG, Rogers WJ, et al. Prevalence, clinical characteristics, and mortality among patients with myocardial infarction presenting without chest pain. Jama 2000;283(24):3223-9. 
7. McCrea WA, Saltissi S. Electrocardiogram interpretation in general practice: relevance to prehospital thrombolysis. Br Heart J 1993;70(3):219-25.

8. The pre-hospital management of acute heart attacks. Recommendations of a Task Force of the The European Society of Cardiology and The European Resuscitation Council. Eur Heart J 1998;19(8):1140-64.

9. Pitt K. Prehospital selection of patients for thrombolysis by paramedics. Emerg Med J. May 2002;19(3):260-3.
10. Prendergast BD. Prehospital thrombolysis. BMJ 5-2003; 327(7405):1-2.

11. Benger JR, Karlsten R, Eriksson B. Prehospital thrombolysis: lessons from Sweden and their application to the United Kingdom. Emerg Med J 2002;19(6):578-83.

12. Smallwood A, Pidgeon J, Kemp $\mathrm{H}$. The introduction of nurse-initiated thrombolysis in coronary care. Br J Nurs. 9-2005 12-2004;13(22):1314-8. 